\title{
Forest landscape mosaics: disturbance, restoration, and management at times of global change
}

In ancient times, human beings believed that the sun revolved around the Earth. Copernicus and Galileo, among others, demonstrated that the opposite was true, that the Earth actually revolved around the sun. In the past, human beings believed that the environment existed solely to serve them. Modern-day Galileos have helped us to understand that we are only a part of the natural world that surrounds us and its continuing health plays a central role in our existence.

Potential effects of hypothesized anthropogenic climate change are raising concerns about the sustainability of development in terms of both people and the rest of the environment. Land use change at the global scale presents many challenges for the research community. Past land use has a definite effect on future ecosystems, but it is challenging to predict future outcomes for biodiversity and productivity of ecosystems. The mechanisms that create complex patterns of forests at different scales (e.g., microscopic, stand-level) will require further systematic analysis.

Ecological investigations have traditionally focused on pristine systems free from human interference. However, as human influence upon ecological systems has become ever more pervasive, there is a growing need for theory to address not only pristine systems, but also those that are highly disturbed. A major challenge for ecologists and land managers to determine is the degree of "naturalness" of a system. How can we adequately define the time and space scale for resilience (Steffen et al. 2015) and what criteria should we use when faced with a novel ecosystem (Laarmann et al. 2015)?

Although forestry has traditionally focused on production of commodities, the threat of global environmental change demands that we adopt a new paradigm of forest management that combines past knowledge with innovative management planning strategies. These forward-looking strategies would consider a full range of potential ecosystem responses and their implementation would promote forests resilient to unanticipated changes and disturbances.

The international conference "Forest landscape mosaics: disturbance, restoration and management at times of global change" was held in Tartu, Estonia, on 11-14 August 2014. This meeting brought together scientists, practitioners, policymakers, and other experts to share knowledge and experiences with disturbance management and evaluate past, present, and potential future application and implementation of research findings from the scientific community.

The initiative came from two working groups within the European Forest Institute (EFINORD) / Nordic Forest Research (SNS): the network of Natural Disturbance Dynamics Analysis for Forest Ecosystem Management (FORDISMAN) and the Nordic Working Group on the Ecology of Primeval Boreal Forests (PRIFOR). Two global research organizations, the International Union of Forest Research Organizations (IUFRO) and the International Association for Vegetation Science (IAVS), supported the conference.

The set of papers presented in this special issue describe conservation and management options for forest ecosystems in different locations. The first four papers characterise disturbance regimes and coarse woody debris. Panayotov et al. investigated the disturbance dynamics of Norway spruce forests in central and southern Europe and found insects and storms to be the most important agents of disturbance. Chećko et al. analysed the importance of deadwood in stand regeneration dynamics and con- cluded that deadwood is crucial for Norway spruce regeneration. Fischer et al. focuses on stand regeneration and composition after a major spruce bark beetle outbreak. Dobrowolska analyses the forest dynamics during the first decade of stand reinitiation, taking into consideration the disturbance severity factor.

The rest of the papers analyse management effects on stand structure and biodiversity. While providing high yields, intensive forestry such as hybrid aspen plantations may severely affect forest plant communities, and Tullus et al. report that although both vascular plants and bryophytes occur in hybrid aspen stands, the composition changes and species number is reduced compared with natural forests. Management effect (salvage logging) is analysed by Parro et al., who show that forest regeneration depends on legacy components: both facilitation and suppression were found. To better understand the options for continuous cover forestry in northern Europe, a number of experimental sites subject to target diameter harvesting in southern Sweden have been established and the initial structural changes are reported by Drössler et al. One paper presents results on the potential for silviculture to mitigate European ash dieback (Rosenvald et al.), and the effect of postdisturbance logging on bird assemblages in winter was evaluated in another paper (Werner et al.). Hedwall and Mikusiński show how absence of natural disturbances may dramatically change forest structure in protected areas. In contrast, Pasanen et al. provide an example of how reintroduction of disturbances can facilitate structural restoration of boreal forests.

Relatively undisturbed remnants ("legacy environments") can provide a template for management of forest stands that are resilient to disturbances, including changing climate, but their elimination or fragmentation can result in a decline in biodiversity (Gauthier et al. 2009). Research can provide guidelines for effective and sustainable management as knowledge of natural vegetation processes is necessary to adequately model forest management scenarios (Kangur et al. 2005) or target ecosystems (Halme et al. 2013). Projections of future disturbances require an understanding of potential disturbances and how to project novel environmental situations (Shifley et al. 2014).

The observational and manipulative research on natural conditions of forests in different climates have produced an enormous amount of data. Further analysis of these valuable datasets is even more important in light of projected worldwide climate change.

\section{Acknowledgements}

The efforts of local organizers Floor Vodde, Ahto Kangur, and Marek Metslaid of the Estonian University of Life Sciences were critical to the successful organization and operation of the conference. Piret Trei deserves particular thanks for her administrative support of the conference organizers. EFIONORD/SNS has sponsored this meeting, as well as earlier meetings of FORDISMAN and PRIFOR networks. The support of the enterprises Artiston and Festforest is greatly appreciated.

\section{References}

Gauthier, S., Vaillancourt, M.-A., Kneeshaw, D., Drapeau, P., De Grandperé, L., Claveau, Y., and Paré, D. 2009. Forest ecosystem management: Origins and foundations. In Ecosystem management in the boreal forest. Edited by S. Gauthier, M.-A. Vaillancourt, A. Leduc, L. De Grandpré, D. Kneeshaw, H. Morin, P. Drapeau, and Y. Bergeron. Presses de l'Université du Québec. pp. 13-37. 
Halme, P., Allen, K.A., Aunins, A., Bradshaw, R.H.W., Brumelis, G., Cada, V., Clear, J.L., Eriksson, A.M., Hannon, G., Hyvarinen, E., Ikauniece, S., Irsenaite, R., Jonsson, B.G., Junninen, K., Kareksela, S., Komonen, A., Kotiaho, J.S., Kouki, J., Kuuluvainen, T., Mazziotta, A., Monkkonen, M., Nyholm, K., Olden, A., Shorohova, E., Strange, N., Toivanen, T., Vanha-Majamaa, I., Wallenius, T., Ylisirnio, A.L., and Zin, E. 2013. Challenges of ecological restoration: lessons from forests in northern Europe. Biol. Conserv. 167: 248-256. doi:10.1016/j. biocon.2013.08.029.

Kangur, A., Korjus, H., Jõgiste, K., and Kiviste, A. 2005. A conceptual model of forest stand development based on permanent sample-plot data in Estonia. Scand. J. For. Res. 20(Suppl. 6): 94-101. doi:10.1080/14004080510041039.

Laarmann, D., Korjus, H., Sims, A., Kangur, A., Kiviste, A., and Stanturf, J.A. 2015. Evaluation of afforestation development and natural colonization on a reclaimed mine site. Restor. Ecol. 39: 301-309. doi:10.1111/rec.12187.

Shifley, S.R., Moser, W.K., Nowak, D.J., Miles, P.D., Butler, B.J., Aguilar, F.X DeSantis, R.D., and Greenfield, E.J. 2014. Five anthropogenic factors that will radically alter forest conditions and management needs in the US North over the next 50 years. For. Sci. 60(5): 914-925. doi:10.5849/forsci.13-153.

Steffen, W., Richardson, K., Rockström, J., Cornell, S.E., Fetzer, I., Bennett, E.M., Biggs, R., Carpenter, S.R., de Vries, W., de Wit, C.A., Folke, C., Gerten, D.,
Heinke, J., Mace, G.M., Persson, L.M., Ramanathan, V., Reyers, B., and Sörlin, S. 2015. Planetary boundaries: Guiding human development on a changing planet. Science, 347: 1259855. doi:10.1126/science.1259855.

Kalev Jõgiste

Estonian University of Life Science, Tartu, Estonia

Bengt Gunnar Jonsson

Mid Sweden University, Sundsvall, Sweden

Timo Kuuluvainen

University of Helsinki, Helsinki, Finland

Sylvie Gauthier

Laurentian Forestry Center, Canadian Forest Service, Sainte-Foy, Quebec, Canada

\section{W. Keith Moser}

Fort Valley Experimental Forest, USDA Forest Service, Flagstaff, Arizona, U.S.A. 